\title{
Diversity of parasites of fish from the Upper Paraná River floodplain, Brazil
}

\author{
Takemoto, RM.*, Pavanelli, GC., Lizama, MAP., Lacerda, ACF., \\ Yamada, FH., Moreira, LHA., Ceschini, TL. and Bellay, S. \\ Programa de Pós-graduação em Ecologia de Ambientes Aquáticos Continentais - PEA, \\ Núcleo de Pesquisas em Limnologia, Ictiologia e Aquicultura - Nupélia, \\ Laboratório de Ictioparasitologia, Universidade Estadual de Maringá - UEM, \\ Av. Colombo, 5790, CEP 87020-900, Maringá, PR, Brazil \\ *e-mail: takemotorm@nupelia.uem.br
}

Received November 27, 2008 - Accepted March 13, 2009 - Distributed June 30, 2009

(With 2 figures)

\begin{abstract}
The aim of the present study was to provide a current survey of the species of parasites found in the Upper Paraná River floodplain, as well as to investigate which strategies and mechanisms used by parasites, are favored and which environmental factors influence the parasite community in the studied environments. During a seven-year period from February 2000 to September 2007, 3,768 fish belonging to 72 species were collected and analyzed for the purpose of studying the parasite fauna. A total of 337 species of parasites were reported, including 12 new descriptions: one myxosporid, Henneguya paranaensis Eiras, Pavanelli and Takemoto, 2004; eight monogeneans, Kritskyia annakohnae Boeger, Tanaka and Pavanelli, 2001; Kritskyia boegeri Takemoto, Lizama and Pavanelli, 2002; Kritskyia eirasi Guidelli, Takemoto and Pavanelli, 2003; Demidospermus labrosi França, Isaac, Pavanelli and Takemoto, 2003; Demidospermus mandi França, Isaac, Pavanelli and Takemoto, 2003; Pseudovancleaveus paranaensis França, Isaac, Pavanelli and Takemoto, 2003; Tereancistrum curimba Lizama, Takemoto and Pavanelli, 2004 and Tereancistrum toksonum Lizama, Takemoto and Pavanelli, 2004; two digeneans, Sanguinicola platyrhynchi Guidelli, Isaac and Pavanelli, 2002 and Dadayius pacupeva Lacerda, Takemoto and Pavanelli, 2003 and one cestode, Nomimoscolex pertierrae Chambrier, Takemoto and Pavanelli, 2005. In addition, several other species were reported for the first time in new hosts or in the floodplain. Monogeneans presented the highest number of species, followed by digeneans. The infection site with the highest species richness was the intestine, with 127 species.
\end{abstract}

Keywords: ichthyoparasites, biodiversity, helminthes, crustaceans, parasite ecology.

\section{Diversidade dos parasitos de peixes da planície de inundação do Alto Rio Paraná, Brasil}

\section{Resumo}

O objetivo do presente trabalho foi realizar um novo levantamento das espécies de parasitos encontradas na planície de inundação do Alto Rio Paraná, bem como investigar quais estratégias e mecanismos utilizados pelos parasitos são mais favorecidos e quais fatores ambientais estão influenciando a comunidade parasitária nos ambientes estudados. Durante o período de fevereiro de 2000 a setembro de 2007, 3.768 espécimes de peixes pertencentes a 72 espécies foram coletados e analisados, visando o estudo da fauna parasitária. Até o momento foram registradas, 337 espécies de parasitos, sendo 12 novas espécies: uma de mixosporídeo, Henneguya paranaensis Eiras, Pavanelli e Takemoto, 2004; oito de monogenéticos, Kritskyia annakohnae Boeger, Tanaka e Pavanelli, 2001; Kritskyia boegeri Takemoto, Lizama e Pavanelli, 2002; Kritskyia eirasi Guidelli, Takemoto e Pavanelli, 2003; Demidospermus labrosi França, Isaac, Pavanelli e Takemoto, 2003; Demidospermus mandi França, Isaac, Pavanelli e Takemoto, 2003; Pseudovancleaveus paranaensis França, Isaac, Pavanelli e Takemoto, 2003; Tereancistrum curimba Lizama, Takemoto e Pavanelli, 2004 e Tereancistrum toksonum Lizama, Takemoto e Pavanelli, 2004; duas de digenéticos, Sanguinicola platyrhynchi Guidelli, Isaac e Pavanelli, 2002 e Dadayius pacupeva Lacerda, Takemoto e Pavanelli, 2003 e uma de cestóide, Nomimoscolex pertierrae Chambrier, Takemoto e Pavanelli, 2005. Além dessas novas espécies, várias outras foram registradas pela primeira vez em novos hospedeiros ou na planície. O grupo dos monogenéticos foi o que apresentou maior número de espécies encontradas, seguido pelos digenéticos. O intestino foi o sítio de infecção que apresentou a maior riqueza, com 127 espécies.

Palavras-chave: ictioparasitos, biodiversidade, helmintos, crustáceos, ecologia de parasitos. 


\section{Introduction}

Floodplains are ecosystems that experience recurrent floods, favoring certain adaptations of the organisms inhabiting them and resulting in the presence of communities with characteristic structures and functions (Junk, et al. 1989). Floods can alter the population dynamics of the ichthyofauna, as well as their physiological and biological conditions, thereby influencing the structure and composition of the parasite fauna. In addition, chemical and physical variables of the water such as dissolved oxygen, temperature and turbulence can contribute to the emergence and increases in the demography of some parasite species (Pavanelli et al., 1997).

Luque and Poulin (2008) reported that differences in the taxonomic diversification of the parasite assemblages of different fish species were mainly related to the environment (higher values in benthic-demersal species), trophic level (positive correlation) and temperature (positive correlation for all groups of parasites in freshwater fishes). Therefore, the Upper Paraná River floodplain, characterized by a wide variety of habitats and species, favors the occurrence of a great diversity of fish parasites.

Lizama et al. (2006a) and Yamada et al. (2007) found higher parasitism indexes of monogeneans and digeneans in open lagoons in the Upper Paraná River floodplain. The authors explain that the presence of morphological adaptations, such as eggs with adhesive appendices that allow for attachment to a substrate, could explain the higher number of monogeneans. Meanwhile, digeneans could be more prevalent in these environments due to the great quantity of intermediate hosts in open lagoons. Studying Pseudoplatystoma corruscans (Spix and Agassiz, 1829) and Schizodon borelli (Boulenger, 1900), Machado et al. (1995) observed that fish were more parasitized by cestodes in semi-lentic environments and by nematodes in lentic environments, probably because of the great variety of prey and availability of shelter.

The parasite fauna of fish from the Upper Paraná River floodplain was previously detailed by Pavanelli et al. (1997, 2004). The present study investigates which reproductive strategies and dispersion mechanisms are favored, and which environmental factors (internal and external) influence the parasite community. In addition, this paper complements previous studies presenting an updated list of species of parasites and hosts.

\section{Materials and Methods}

All fish were collected in the floodplain of the Upper Paraná River, Brazil, from February 2000 to September 2007. Fishes were captured using gill nets, and parasites were collected with the aid of a stereoscopic microscope. The eyes, skin, fins, gills, nostrils and mouth cavity of the selected individuals were studied for ectoparasites. The body cavity was opened to examine the liver, stomach, pyloric caeca, intestine and gonads microscopically for endoparasites (see Eiras et al., 2006).
The literature used to identify the parasites included original descriptions. Quantitative information on the prevalence and intensity of infection by different parasites and on parasite community descriptors have been published previously for the following fish species: Prochilodus lineatus (Valenciennes, 1837) (Takemoto et al., 2002; Eiras et al., 2004; Lizama et al., 2004; 2005; 2006a, b); Acestrorhynchus lacustris (Lütken, 1875) (Carvalho et al., 2003); Iheringichthys labrosus (Lütken, 1874) (França et al., 2003); Hemisorubim platyrhynchos (Valenciennes, 1840) (Guidelli et al., 2003a); Leporinus spp. (Guidelli et al., 2003b; 2006); Metynnis maculatus (Kner, 1858) (= M. lippincottianus) (Lacerda et al., 2003); A. lacustris, S. borellii, $P$. lineatus, Serrasalmus marginatus Valenciennes, 1837 and S. maculatus Kner, 1858 (Lacerda et al., 2007); Potamotrygon spp. (Lacerda et al., 2008; 2009); Hoplias aff. malabaricus (Bloch, 1794), Satanoperca pappaterra (Heckel, 1840), Plagioscion squamosissimus (Heckel, 1840), Crenicichla britskii Kullander, 1982, Cichla monoculus Spix and Agassiz, 1831 (= C. kelberi) and Cichlasoma paranaense Kullander, 1983 (Aoyama et al., 2005); P. squamosissimus (Tavernari et al., 2005); P. corruscans (Chambrier et al., 2006); Loricariichthys platymetopon Isbrücker and Nijssen, 1979 (Ferrari et al., 2007); S. papaterra (Yamada et al., 2007) and Cichla spp. (Yamada et al., 2008).

\section{Results}

We collected and analyzed 3,768 fish belonging to 72 species. A total of 337 species of parasites were reported (Appendix 1), including the description of 12 new species: one myxosporid, Henneguya paranaensis Eiras, Pavanelli and Takemoto, 2004; eight monogeneans, Kritskyia annakohnae Boeger, Tanaka and Pavanelli, 2001; K. boegeri Takemoto, Lizama and Pavanelli, 2002; K. eirasi Guidelli, Takemoto and Pavanelli, 2003; Demidospermus labrosi França, Isaac, Pavanelli and Takemoto, 2003; D. mandi França, Isaac, Pavanelli and Takemoto, 2003; Pseudovancleaveus paranaensis França, Isaac, Pavanelli and Takemoto, 2003; Tereancistrum curimba Lizama, Takemoto and Pavanelli, 2004 e T. toksonum Lizama, Takemoto and Pavanelli, 2004; two digeneans, Sanguinicola platyrhynchi Guidelli, Isaac and Pavanelli, 2002 and Dadayius pacupeva Lacerda, Takemoto and Pavanelli, 2003 and one cestode, Nomimoscolex pertierrae Chambrier, Takemoto and Pavanelli, 2006.

In total, 12 groups of parasites were collected, mainly Platyhelminthes (Monogenea, Digenea and Cestoda) and Nematoda. Among the groups of parasites found, monogeneans presented the greatest number of species with 82 (Figure 1), including species that parasitized gills, nasal fossae and urinary bladder. Among digeneans and nematodes, which also presented high numbers of species, adults and larval forms were observed. Sixty-nine species of digeneans were recorded, with 28 reported as larvae. 


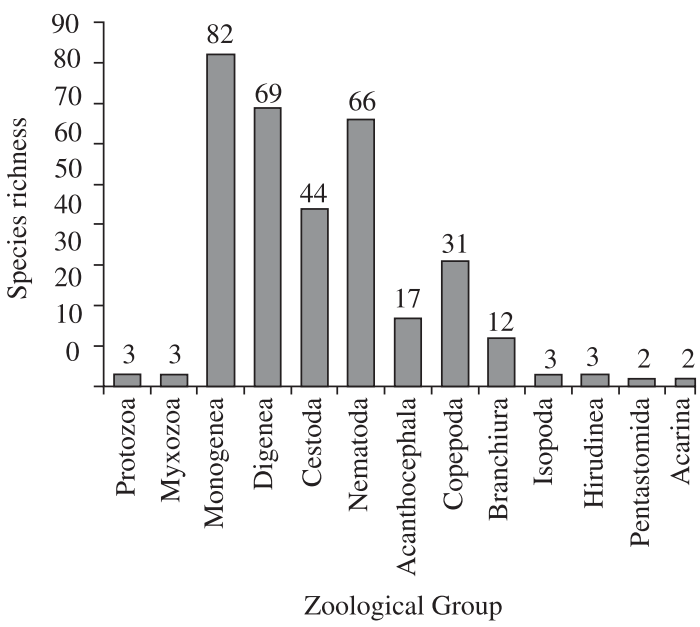

Figure 1. Species richness of fish parasites according to zoological group reported in the Upper Paraná River floodplain.

Nine out of 66 species of nematodes were larvae, and Contracaecum sp. (Anisakidae) was the most common.

The main infection site was the intestine, which was parasitized by 127 different species of parasites, including digeneans, cestodes, nematodes and acanthocephalans. These species were always found as adults (Figure 2). The gills presented the second highest number of species (91), mainly monogeneans and copepods. In the mesentery, the helminthes were mainly larval forms.

The parasitic protozoa are usually classified according to their motility mechanisms. These include amoeboid, flagellated, and ciliated forms. Among the protozoa, three species of Phylum Sarcomastigophora were reported: Trypanosoma guairaensis Eiras, Rego and Pavanelli, 1989, T. scrofae Eiras and Pavanelli, 1989 and T. nupelianus Eiras, Rego and Pavanelli, 1990, parasitizing Megalancistrus parananus (Peters, 1881), P. lineatus and Rhineleps aspera Spix and Agassiz, 1829, respectively.

The myxozoans, which until recently were considered protozoans, are now considered metazoans. The genus Henneguya was reported in the floodplain, with the description of a new species, $H$. paranaensis Eiras, Pavanelli and Takemoto, 2004.

During this period, the class Monogenea had the largest number of new species.

Digeneans presented the second highest number of species and low host specificity. Some species that parasitize fish in the larval stage, such as Diplostomum (Austrodiplostomum) compactum (Lutz, 1928) (probably introduced), were reported in nine different species of hosts: $H$. aff. malabaricus, $S$. pappaterra, P. squamosissimus, C. britskii, Cichla kelberi Kullander and Ferreira, 2006 (= Cichla monoculus), C. paranaense, Hypostomus regani (Ihering, 1905), S. borellii, and Auchenipterus osteomystax (Miranda Ribeiro, 1918).

Nematodes also generally have low host specificity, such as the nematode Procamallanus (Spirocamallanus)

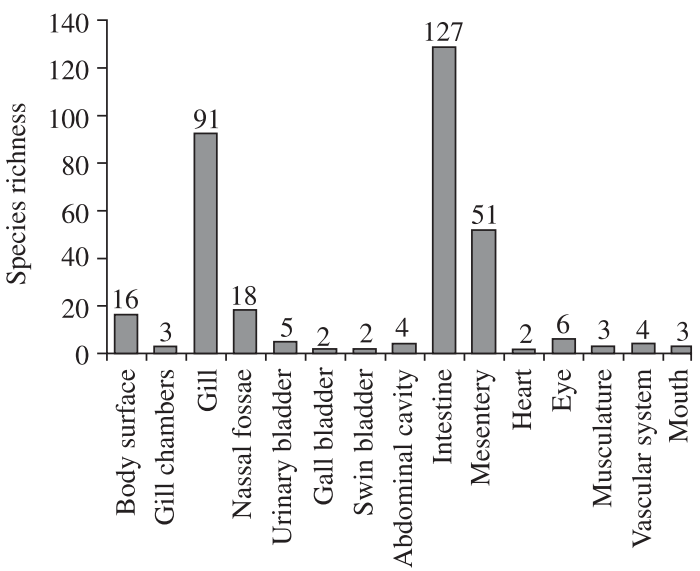

Site of infestation/ infection

Figure 2. Species richness according to the site of infection/ infestation reported in the Upper Paraná River floodplain.

inopinatus Travassos, Artigas and Pereira, 1928, which was reported in nine different species of hosts (S. marginatus, S. maculatus, S. borelli, H. aff. malabaricus, M. lippincottianus, Leporinus elongatus Valenciennes, 1850, L. obtusidens (Valenciennes, 1837), L. lacustris Amaral Campos, 1945 and P. corruscans) in the current study. However, Moravec (1998) had already registered this species in more than 40 species of fish from the Neotropical region. Another species of nematode that presented low specificity was the larvae of Contracaecum sp., which was already reported in 17 different species of hosts. This species deserves special attention because it parasitizes fish as larvae, using it as an intermediate host and then presenting zoonotic potential.

During this period only one species of cestode was described, Nomimoscolex pertierrae Chambrier, Takemoto and Pavanelli, 2006. In previous studies, the occurrence of this group was observed mainly in Siluriform fishes and with high host specificity. Considering only the fish "pintado", P. corruscans and "jaú", Zungaro zungaro (Humboldt, 1821) (= Paulicea luetkeni), six species of proteocephalideans were reported in each species, all adults. Larval stages of Cyclophyllidea were also reported, including Valipora campylancristrota (Wedl, 1855) in P. lineatus, Pimelodus maculatus Lacépède, 1803 and Hoplosternum littorale (Hancock, 1828), all parasitizing the gall bladder. In the stingrays Potamotrygon motoro (Müller and Henle, 1841) and P. falkneri Castex and Maciel, 1963, cestodes of orders Tetraphyllidea, Acanthobothrium regoi Mayes, Brooks and Thorson, 1981, Rhinebothrium paratrygoni Rego and Dias, 1976, Potamotrygonocestus travassosi Rego, 1979 and Trypanorhyncha, Paroncomegas araya (Woodland, 1934) were reported.

Among the acanthocephalans, Quadrigyrus machadoi Fabio, 1983 presented low specificity, occurring in seven different species of hosts (P. motoro, 
P. falkneri, H. aff. malabaricus, Gymnotus carapo Linnaeus, 1758, P. maculatus, H. platyrhynchos and C. kelberi). Acanthocephalans of the genus Quadrigyrus occurred as adults and larvae.

The main families of Copepoda reported in the floodplain were Ergasilidae and Vaigamidae, parasitizing the branchial arcs and the nostrils, respectively. In addition, copepods of family Therodamasidae were observed parasitizing the branchial arcs of $P$. maculatus. This family is characterized by an anterior structure that penetrates into the tissues of the branchial arcs of the host, causing considerable lesions. This is the first record of this family in the Upper Paraná River floodplain.

Branchiura, Isopoda, Hirudinea, Pentastomida and Acarina presented low species diversity.

\section{Discussion}

In previous studies, Takemoto et al. (2004) reported 184 species of fish parasites in the Upper Paraná River floodplain. Currently, 337 species are known. This augmentation of species richness is due to the increase in the quantity of studies conducted in recent years, which have included different species of fish.

In addition to the previously described species, several other species were reported for the first time in the floodplain. In P. maculatus, for example, we reported the first copepods of the family Therodamasidae, and this is also the first record for the Upper Paraná River basin.

Myxozoa is a group of parasitic organisms for which the basic knowledge regarding phylogenetic affinities and life cycles has changed dramatically in the last two decades. The myxozoans were included as unicellular protozoans. However, according to Smothers et al. (1994) and Siddall et al. (1995), recent evidence clearly indicates that myxozoans are true metazoans. In the Upper Paraná River floodplain, only the genus Henneguya was observed.

Monogenea is the group that has presented the greatest number of species so far. Monogeneans are a diverse group of parasites that exhibit a relatively high degree of host specificity when compared to other groups of parasites. Because monogeneans do not represent a zoonotic problem for humans, and because most of them are not pathogenic, very little is known about the biology of most species (Bush et al., 2001).

The number of species recorded in this class tends to increase in the floodplain, since previous studies have already shown its high species richness in every species of host.

Among the groups of parasites found, digeneans presented the second highest number of species (69), including adults and larval stages. Some species of digeneans presented low specificity and were mainly present in larval forms. As an example we can cite $D$. (A.) compactum, a digenean that, in the metacercaria stage, parasitizes the eyes of fish. This parasite was probably introduced to the floodplain with $P$. squamosissimus. Despite being almost an obligatory parasite of this species, we noticed that in recent years, the number of species of parasitized hosts has increased considerably. We recorded this digenean in nine species of fish, showing low specificity and rapid adaptation to the new environment.

The conservation of the native fauna depends on research to increase knowledge regarding which parasites spread globally (Font, 2003). The goal of ecologists is not only to document the distribution of parasites, but also to determine methods by which parasites can disperse to new areas. Through the determination of the groups of parasites that can establish themselves in a new environment, it is possible to determine which strategies of reproduction are favored. Improved understanding of these mechanisms of dispersion can increase the chances of limiting the dispersion of certain parasites (Font, 2003).

Digeneans represent the highest number of species because fish can act as intermediate hosts, harboring larval stages, and also as definitive hosts, harboring adult forms. Moreover, the majorities of the fish examined here occupy intermediate levels in the food chain and can be parasitized by both forms.

Another larvae that showed low specificity was the nematode Contracaecum sp. This species belongs to the family Anisakidae and is of great importance in public health because of its high zoonotic potential. Anisakids are important to humans on a number of counts: economically, politically and mainly pathologically. Paratenic hosts are often fish that are important for human consumption. The worms do not mature in humans and the pathology is mostly associated with penetration of the small intestine and stomach by the larvae. The degree of discomfort is likely a consequence of the number of larvae penetrating. In rare cases, humans have died from anisakiasis due to severe peritonitis (Bush et al., 2001). However, there are no records of this zoonosis in the region and this is probably due to the fact that all of the larvae of this species were encysted in the mesentery, which is not used for human consumption.

The occurrence of a few species of some groups may be due to the absence or low number of certain hosts required for a particular stage of the developmental cycle. This is probably the case for the pentastomids that parasitize fish as larvae and alligators as adults. Although there are alligators in the floodplain, their numbers are relatively small when compared to other regions. The pentastomids are a small group of parasites that includes about 100 species. Studies on the phylogenetic relationships of the Pentastomida, a group traditionally treated as a separate phylum, suggest that they are truly arthropods with possible affinities for the crustacean (Bush et al., 2001).

The diversity of endohelminths can vary according to the environment or the species of host, and can be related to the size, longevity and particularly the food of the host. The intermediate host is necessarily part of the diet of the definitive host (Luque and Poulin, 2008). Furthermore, fish with a longer lifespan present more 
time of exposure to parasites, favoring cumulative processes in the host.

In the Upper Paraná River floodplain, Takemoto et al. (2005) studied the effects of several host traits (body size, social behavior, reproductive behavior, spawning type, trophic category, feeding habits, relative position in the food web, preference for certain habitats and whether the fish species are native or exotic) on metazoan endoparasite species richness. The CPUE (number of individuals of a given fish species captured per $1,000 \mathrm{~m}^{2}$ of net during 24 hours) was the sole significant predictor of parasite species richness, regardless of control for the confounding influences of host phylogeny and sampling effort. The results suggest that in the Upper Paraná River floodplain (with homogeneous physical characteristics and occurrence of many flood pulses), population density of different host species might be the major determinant of the parasite species richness. This result is in concordance with epidemiological theory predicting that hosts with larger or denser populations will more readily sustain several parasite populations. Because parasites in this study use fish as either intermediate or definitive hosts, depending on species, this situation might reflect a combination of large intermediate and definitive host populations facilitating parasite transmission and reproduction, respectively. However, it is important to mention that the cited study was developed utilizing data obtained from 1986 to 2003, and current floods pulses do not occur periodically as they used to because of the construction of several hydroelectric power plants upstream from the studied area.

To date, 182 species of fish have been registered in the Upper Paraná River floodplain (Graça and Pavanelli, 2007). If we assume that each species of host can harbor an average of ten species of parasites (Takemoto et al., 2004), there should be about 1,820 species of parasites in the floodplain. However, in the present study we recorded less than 350 species of parasites, with many more to be studied. This number, however, may be much higher, considering that in some hosts such as $P$. lineatus, 33 species of parasites were reported.

To understand the role of the community of parasites in an ecosystem, previous knowledge of the species that compose it is required. Continuation of studies using taxonomic and systematic approaches is the key to understanding how biotic and abiotic factors affect species, since there is no way to understand the effects on a population without knowing the species.

Acknowledgements - We would like to express our gratitude to several people who helped us to obtain the data presented in this work: Gislaine M Guidelli, Patrícia M Machado Aoyama, Andréia Isaac, Solange de Carvalho, Ana Paula Ferrari, Jakeline G França, Fernando de C Tavernari, Kennya F Ito, Sara T Moreira, Eliane da S Fernandes, Luciana MS Hino, Letícia C Karling, Filipe MS Alvarenga, Paula G Milani and Ana Cláudia Munhoz RM Takemoto and GC Pavanelli were supported by a Research Fellowship from CNPq (Conselho Nacional de Pesquisa e Desenvolvimento Tecnológico, Brazil). ACF Lacerda, FH Yamada and S Bellay were supported by Masters
Scholarships from CAPES (Coordenação de Aperfeiçoamento de Pessoal de Nível Superior). LHA Moreira was also supported by CNPq (Master Scholarship).

\section{References}

AOYAMA, PMM., TAKEMOTO, RM. and PAVANELLI, GC., 2005. Diplostomum (Austrodiplostomum) compactum (Lutz, 1928) (Platyhelminthes, Digenea) metacercariae in fish from the Floodplain of the Upper Paraná River, Brazil. Parasitology Research, vol. 97, no. 6, p. 436-444.

BUSH, AO., FERNÁNDEZ, JC., ESCH, GW. and SEED, JR., 2001. Parasitism: the diversity and ecology of animal parasites. Cambridge: Cambridge University Press. 566p.

CARVALHO, S., GUIDELLI, GM., TAKEMOTO, RM. and PAVANELLI, GC., 2003. Ecological aspects of endoparasite fauna of Acestrorhynchus lacustris (Lutken, 1875) (Characiformes, Acestrorhynchidae) on the Upper Paraná River Floodplain, Brazil. Acta Scientiarum, vol. 25, no. 2, p. $479-483$.

CHAMBRIER, A., TAKEMOTO, RM. and PAVANELLI, GC., 2006. Nomimoscolex pertierrae n. sp. (Eucestoda: Proteocephalidea), a parasite of Pseudoplatystoma corruscans (Siluriforme: Pimelodidae) in Brazil and redescription of $N$. sudobim Woodland, 1935, a parasite of P. fasciatum. Systematic Parasitology, vol. 64, no. 3, p. 191-202.

EIRAS, JC., PAVANELLI, GC. and TAKEMOTO, RM., 2004. Henneguya paranaensis sp. n. (Myxozoa, Myxobolidae), a parasite of the teleost fish Prochilodus lineatus (Characiformes, Prochilodontidae) from the Paraná river, Brazil. Bulletin of the European Association of Fish Pathologists, vol. 24, no. 6, p. $308-311$.

EIRAS, JC., TAKEMOTO, RM. and PAVANELLI, GC., 2006. Métodos de estudo e técnicas laboratoriais em parasitologia de peixes. 2 ed. Maringá: Eduem. 199p.

FERRARI, AP., TAKEMOTO, RM. and PAVANELLI, GC., 2007. Digenetic trematodes parasites of Loricariichthys platymetopon (Loricariidae, Siluriformes) of the Upper Paraná River Floodplain, Brazil. Acta Scientiarum, vol. 29, no. 3, p. 327-329.

FONT, WF., 2003. The global spread of parasites: what do Hawaiian Streams tell us? Bioscience, vol. 53, no. 11, p. 1061-1067.

FRANÇA, JG., ISAAC, A., PAVANELLI, GC. andTAKEMOTO, RM., 2003. Dactylogyridae (Monogenea) from the gills of Iheringichthys labrosus (Osteichthyes: Pimelodidae) from the upper Paraná River floodplain, Brazil, with the proposal of Pseudovancleaveus n.g. Systematic Parasitology, vol. 54, no. 1, p. 25-31.

GRAÇA, WJ. and PAVANELLI, CS., 2007. Peixes da planície de inundação do Alto rio Paraná e áreas adjacentes. Maringá: Eduem. 241p.

GUIDELLI, GM., ISAAC, A., PAVANELLI, GC. and TAKEMOTO, RM., 2003a. Endoparasites infracommunities of Hemisorubim platyrhynchos (Valenciennes, 1840) (Pisces, Pimelodidae) of the Baia river, upper Paraná river floodplain, Brazil: specific composition and ecological aspects. Revista Brasileira de Biologia = Brazilian Journal of Biology, vol. 63, no. 2, p. 261-268. 
GUIDELLI, GM., TAKEMOTO, RM. and PAVANELLI, GC., 2003b. A new species of Kritskyia (Dactylogyridae, Ancyrocephalinae) parasite of urinary bladder and ureters of Leporinus lacustris (Characiformes, Anostomidae) from Brazil. Acta Scientiarum, vol. 25, no. 2, p. 279-282.

GUIDELLI, GM., TAVECHIO, WL., TAKEMOTO, RM. and PAVANELLI, GC., 2006. Fauna parasitária de Leporinus lacustris e Leporinus friderici (Characiformes, Anostomidae) da Planície de Inundação do Alto Rio Paraná, Brasil. Acta Scientiarum, vol. 28 , no. 3, p. 281-290.

JUNK, WJ., BAYLY, PB. and SPARKS, RE.., 1989. The flood pulse concept in river-floodplain systems. Canadian Journal of Fishers and Aquatic Sciences, vol. 106, p. 110-127.

LACERDA, ACF., TAKEMOTO, RM., LIZAMA, MAP. and PAVANELLI, GC., 2007. Parasitic copepods in the nasal fossae of five fish species (Characiformes) from the upper Paraná River floodplain, Paraná, Brazil. Acta Scientiarum, vol. 29, no. 4, p. 429-435.

LACERDA, ACF., TAKEMOTO, RM. and PAVANELLI, GC., 2003. A new species of Dadayius Fukui, 1929 (Digenea: Cladorchiidae), parasite of the intestinal tract of Metynnis maculatus (Kner, 1858) (Characidae) from the Upper Paraná River floodplain, Brazil. Acta Scientiarum, vol. 25, no. 2, p. 283-285.

,2008. Digenea, Nematoda,Cestoda, andAcanthocephala, parasites in Potamotrygonidae (Chondrichthyes) from the upper Paraná River floodplain, states of Paraná and Mato Grosso do Sul, Brazil. Check List, vol. 4, no. 2, p. 115-122.

2009. Ecology of endoparasites of the fluvial stingray Potamotrygon falkneri and P. motoro (Chondrichthyes: Potamotrygonidae) from the upper Paraná river, Brazil. Revista Brasileira de Biologia = Brazilian Journal of Biology. vol. 69, no 2, p. 93-99.

LIZAMA, MAP., TAKEMOTO, RM. and PAVANELLI, GC., 2004. New species of Tereancistrum Kritsky, Thatcher \& Kayton, 1980 (Monogenea: Dactylogyridae: Ancyrocephalinae) from the gills of Prochilodus lineatus (Osteichthyes: Prochilodontidae) from the upper Paraná River floodplain, Brazil. Systematic Parasitology, vol. 57, no. 1, p. 45-49.

2005. Influence of host sex and age on infracommunities of metazoan parasites of Prochilodus lineatus (Valenciennes, 1836) (Prochilodontidae) of the Upper Paraná River floodplain, Brazil. Parasite, vol. 12, no. 4, p. 299-304.

2006a. Influence of the seasonal and environmental patterns and host reproduction on the metazoan parasites of Prochilodus lineatus (Valenciennes, 1836) (Prochilodontidae) of the Upper Paraná River floodplain, Brazil. Brazilian Archives of Biology and Technology, vol. 49, no. 4, p. 611-622.

2006b. Parasitism influence on the Hepato, Splenosomatic and Weight/Length relation and Relative Condition Factor of Prochilodus lineatus (Valenciennes, 1836) (Prochilodontidae) of the Upper Paraná River Floodplain, Brazil. Revista Brasileira de Parasitologia Veterinária, vol. 15, no. 3, p. 116-122.

LUQUE, JL. and POULIN, R., 2008. Linking ecology with parasite diversity in Neotropical fishes. Journal of Fish Biology, vol. 72 , no. 1, p. 189-204

MACHADO, MH., PAVANELLI, GC. and TAKEMOTO, RM., 1995. Influence of the type of environment and the hidrological level variation in the endoparasitic infrapopulations of Pseudoplatystoma corruscans and Schizodon borelli (Osteichthyes) of the high river Paraná. Revista Brasileira de Zoologia, vol. 12, no. 4, p. 961-976.

MORAVEC, F., 1998. Nematodes of freshwater fishes of the neotropical region. Praha: Academia. 464p.

PAVANELLI, GC., MACHADO, MH., TAKEMOTO, RM., 1997. Fauna helmíntica de peixes do rio Paraná, região de Porto Rico, Paraná. In VAZZOLER, AEAM., AGOSTINHO, AA. and HAHN, NS. (Eds.). A Planície de inundação do Alto rio Paraná: aspectos físicos, biológicos e sócioeconômicos. Maringá: Eduem. p. 307-329.

PAVANELLI, GC., MACHADO, MH., TAKEMOTO, RM., GUIDELLI, GM. and LIZAMA, MAP., 2004. Helminth fauna of fishes: diversity and ecological aspects. In THOMAZ, SM., AGOSTINHO, AA. and HAHN, NS. (Eds.). The Upper Paraná river and its Floodplain: physical aspects, ecology and conservation. Leiden: Backhuys Publishers. p. 309-329.

SIDDALL, ME., MATIN, DS., BRIDGE, D., DESSER, SS. and CONE, DL., 1995. The demise of a phylum protists: phylogeny of Myxozoa and other parasitic Cnidaria. Journal of Parasitology, vol. 81, no. 6, p. 961-967.

SMOTHERS, JF., Von DOHLEN, CD., SMITH Jr., LH. and SPALL, RD., 1994. Molecular evidence that myxozoan protists are metazoans. Science, vol. 265, no. 5179, p. 1719-1721.

TAKEMOTO, RM., LIZAMA, MAP. and PAVANELLI, GC., 2002. A new species of Kritskyia (Dactylogyridae, Ancyrocephalinae) parasite of urinary bladder of Prochilodus lineatus (Prochilodontidae, Characiformes) from the floodplain of the high Paraná river, Brazil. Memórias do Instituto Oswaldo Cruz, vol. 97, no. 3, p. 313-315.

TAKEMOTO, RM., LIZAMA, MAP., GUIDELLI, GM. and PAVANELLI, GC., 2004. Parasitos de peixes de águas continentais. In RANZANI-PAIVA, MJT., TAKEMOTO, RM. and LIZAMA, MAP. (Eds.). Sanidade de organismos aquáticos. São Paulo: Editora Varela. p. 179-197.

TAKEMOTO, RM., PAVANELLI, GC., LIZAMA, MAP., LUQUE, JL. and POULIN, R., 2005. Host density as a major determinant of endoparasite species richness in fishes of floodplain of the upper Parana River, Brazil. Journal of Helminthology, vol. 79, no. 1, p. 75-84.

TAVERNARI, FC., BELLAY, S., TAKEMOTO, RM., GUIDELLI, GM., LIZAMA, MAP. and PAVANELLI, GC., 2005. Ecological aspects of Diplectanum piscinarius (Platyhelminthes, Monogenea) parasite of gills of Plagioscion squamosissimus (Osteichthyes, Sciaenidae) in the Upper Paraná River floodplain, Brazil. Acta Scientiarum, vol. 27, no. 3, p. 225-229.

YAMADA, FH., TAKEMOTO, RM. and PAVANELLI, GC., 2007. Ecological aspects of ectoparasites from gills of Satanoperca pappaterra (Heckel, 1840) (Cichlidae) from the Upper Paraná River floodplain, Brazil. Acta Scientiarum, vol. 29 , no. 3 , p. $331-336$

2008. Relação entre fator de condição relativo $(\mathrm{Kn})$ e abundância de ectoparasitos de brânquias em duas espécies de ciclídeos da bacia do rio Paraná, Brasil. Acta Scientiarum, vol. 30 , no. 2, p. 213-217. 
Appendix 1. Species list of hosts (arranged by family) and parasites reported by Pavanelli et al. $(1997,2004)$ and the present work in the Upper Paraná River floodplain.

\section{CHONDRICHTHYES}

\section{Species list}

\section{MYLIOBATIFORMES}

Potamotrygonidae

- Potamotrygon motoro

(Müller and Henle, 1841) (raia)

Cestoda

Acanthobothrium regoi

Mayes, Brooks and Thorson, 1981

Rhinebothrium paratrygoni

Rego and Dias, 1976

Acanthocephala

Quadrigyrus machadoi Fabio, 1983

\section{- Potamotrygon falkneri}

Castex and Maciel, 1963 (raia)

Digenea

Clinostomum complanatum

Rudolphi, 1814 (metacercariae)

Tylodelphis sp. (metacercariae)

Genarchella sp.

Cestoda

Acanthobothrium regoi

Mayes, Brooks and Thorson, 1981

Rhinebothrium paratrygoni

Rego and Dias, 1976

Potamotrygonocestus travassosi Rego, 1979

Paroncomegas araya (Woodland, 1934)

Nematoda

Brevimulticaecum sp. (larvae)

Cucullanus sp.

Echinocephalus sp.

Spinitectus sp.

Acanthocephala

Quadrigyrus machadoi Fabio, 1983

\section{OSTEICHTHYES}

\section{CHARACIFORMES}

\section{Characidae}

- Aphyocharax anisitsi

Eigenmann and Kennedy, 1903 (piqui)

Monogenea

Digenea

Diplostomidae

Cestoda

Proteocephalidea (plerocercoid)

Nematoda

Acanthocephala

Quadrigyrus sp.

\section{- Psellogrammus kennedyi}

(Eigenmann, 1903) (lambari)

Digenea

Diplostomidae

Cestoda

Proteocephalidea (plerocercoid)

Nematoda
Appendix 1. Continued..

\begin{tabular}{l}
\hline Species list \\
\hline Contracaecum sp. (larvae) \\
Acanthocephala \\
Quadrigyrus sp. (larvae) \\
- Serrapinus notomelas (Eigenmann, 1915) (pequira) \\
Cysts
\end{tabular}

\section{- Astyanax altiparanae}

Garutti and Britski, 2000 (tambiú)

Monogenea

Urocleidoides sp.

Amphithecium sp.

Digenea

Clinostomum sp. (metacercariae)

Herpetodiplostomum sp. (metacercariae)

Tylodelphys sp. (metacercariae)

Ascocotyle sp. (metacercariae)

Antorchis sp. (metacercariae)

Bucephalidae (metacercariae)

Cestoda

Proteocephalidea (plerocercoid)

Nematoda

Procamallanus (Spirocamallanus) caballeroi

Bashirullah, 1977

Contracaecum sp. (larvae)

Spiroxys sp.

Acanthocephala

Quadrigyrus sp.

Copepoda

Brasergasilus sp.

Ergasilus sp.

Vaigamus sp.

Acusicola sp.

- Moenkhausia intermedia

Eigenmann, 1908 (lambari)

Digenea

Copepoda

\section{- Moenkhausia sanctaefilomenae}

(Steindachner, 1907) (lambari-do-olho-vermelho)

Monogenea

Jainus hexops Kritsky and Leiby, 1972

- Roeboides descalvadensis Fowler, 1932 (dentudo)

Digenea (metacercariae)

Monogenea

Jainus sp.

Demidospermus sp.

Acanthocephala

Quadrigyrus sp. (larvae)

Copepoda

- Salminus brasiliensis (Cuvier, 1816) (dourado)

Myxosporea

Digenea

Neocladocystis intestinalis (Vaz,1932)

Prosthenhystera obesa (Diesing, 1850)

Monogenea 
Appendix 1. Continued...

\begin{tabular}{l}
\hline \multicolumn{1}{c}{ Species list } \\
\hline Jainus sp. \\
Anacanthorus sp. \\
Rhinoxenus bulbovaginatus \\
Boeger, Domingues and Pavanelli, 1995 \\
Cestoda \\
Monticellia coryphicephala (Monticelli, 1891) \\
Nematoda \\
Eustrongylides ignotus \\
Jäegerskiold, 1909 (larvae) \\
Anisakidae \\
Branchiura \\
Dolops longicauda (Heller, 1857) \\
Dolops sp.
\end{tabular}

\section{- Acestrorhynchus lacustris}

(Lütken, 1875) (peixe-cachorro)

Monogenea

Digenea

Rhipidocotyle gibsoni

Kohn and Fernandes, 1994

Clinostomum sp. (metacercariae)

Cestoda

Nematoda

Contracaecum sp. (larvae)

Procamallanus sp. (larvae)

Eustrongylides sp. (larvae)

Philometridae

Acanthocephala

Quadrigyrus torquatus Van Cleave, 1920

Copepoda

Rhinergasilus piranhus

Boeger and Thatcher, 1988

\section{- Galeocharax knerii}

(Steindachner, 1879) (peixe-cadela)

Cestoda

Proteocephalidea

Isopoda

\section{- Brycon orbignyanus}

(Valenciennes, 1850) (piracanjuba)

Nematoda (larvae)

\section{Serrasalmidae}

- Serrasalmus marginatus

Valenciennes, 1837 (piranha)

Monogenea

Kritskyia annakohnae

Boeger, Tanaka and Pavanelli, 2001

Rhinoxenus sp.

Anacanthorus sp.1

Anacanthorus sp.2

Anacanthorus sp. 3

Amphithecium sp.

Digenea

Ascocotyle sp. (metacercariae)

Nematoda

Procamallanus (Spirocamallanus) inopinatus Travassos, Artigas and Pereira, 1928
Appendix 1. Continued...

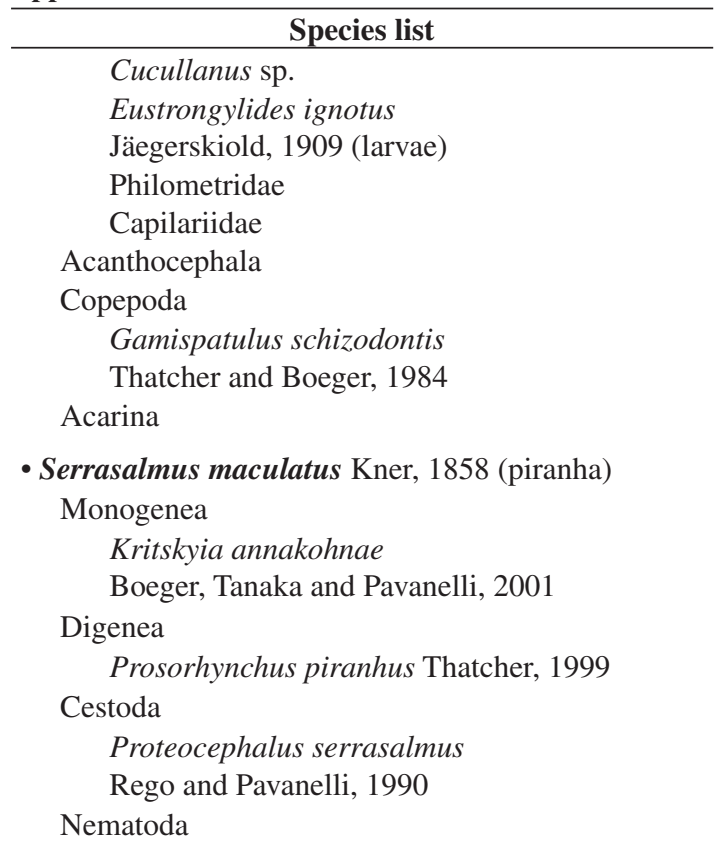

Procamallanus (Spirocamallanus) inopinatus Travassos, Artigas and Pereira, 1928

Cucullanus sp.

Eustrongylides ignotus

Jäegerskiold, 1909 (larvae)

Philometridae

Capilariidae

Acanthocephala

Copepoda

Gamispatulus schizodontis

Thatcher and Boeger, 1984

- Myloplus cf. tiete

Eigenmann and Norris, 1900 (pacu-prata)

Digenea

- Metynnis lippincottianus (Cope, 1870) (pacu-peva)

Digenea

Dadayius pacupeva

Lacerda, Takemoto and Pavanelli, 2003

Nematoda

Procamallanus (Spirocamallanus) inopinatus

Travassos, Artigas and Pereira, 1928

Spinoxyuris oxydoras Petter, 1994

Raphidascaris (Sprentascaris) mahnerti

(Petter and Cassone, 1984)

Contracaecum sp.

- Piaractus mesopotamicus (Holmberg, 1887) (pacu)

Digenea

Dadaytrema oxycephala (Diesing, 1836)

Cestoda

Proteocephalus vazollerae

Pavanelli and Takemoto, 1995

Nematoda

Rondonia rondoni Travassos, 1920

Acanthocephala 
Appendix 1. Continued...

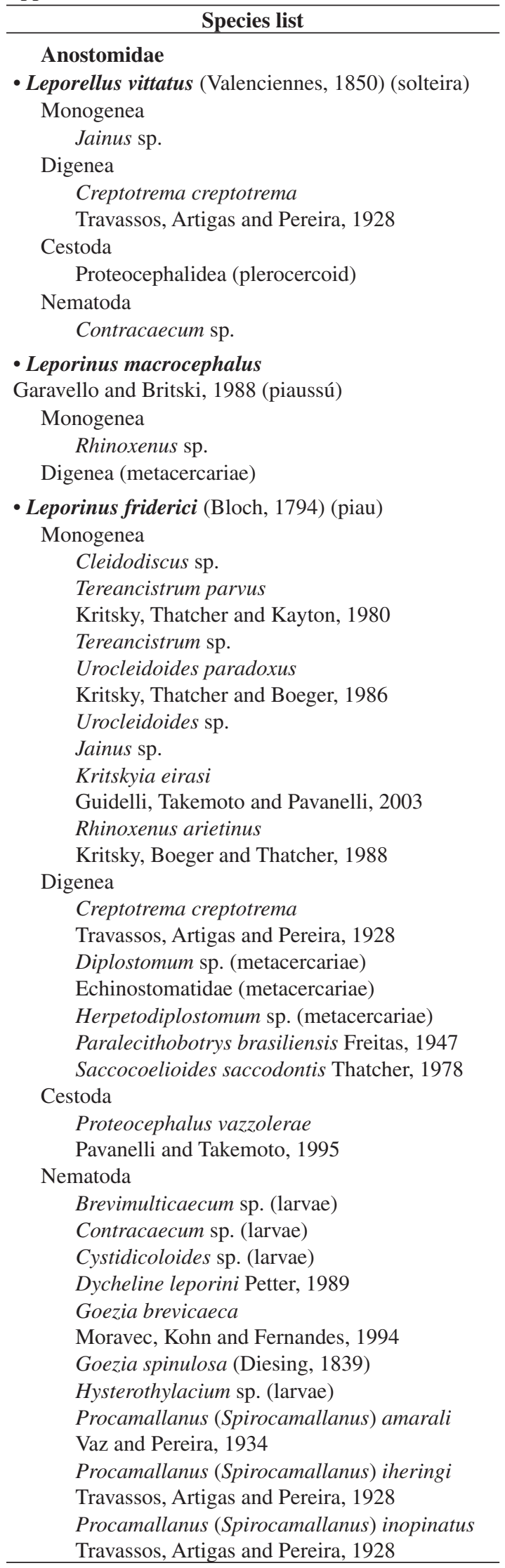

Appendix 1. Continued...

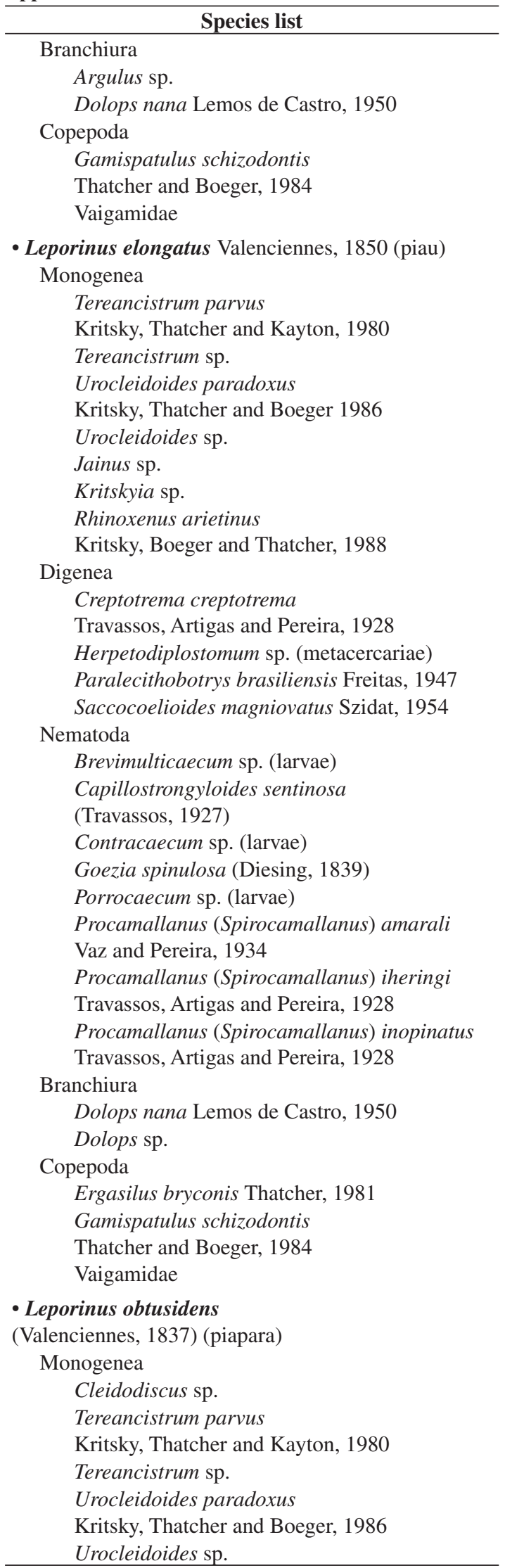


Appendix 1. Continued...

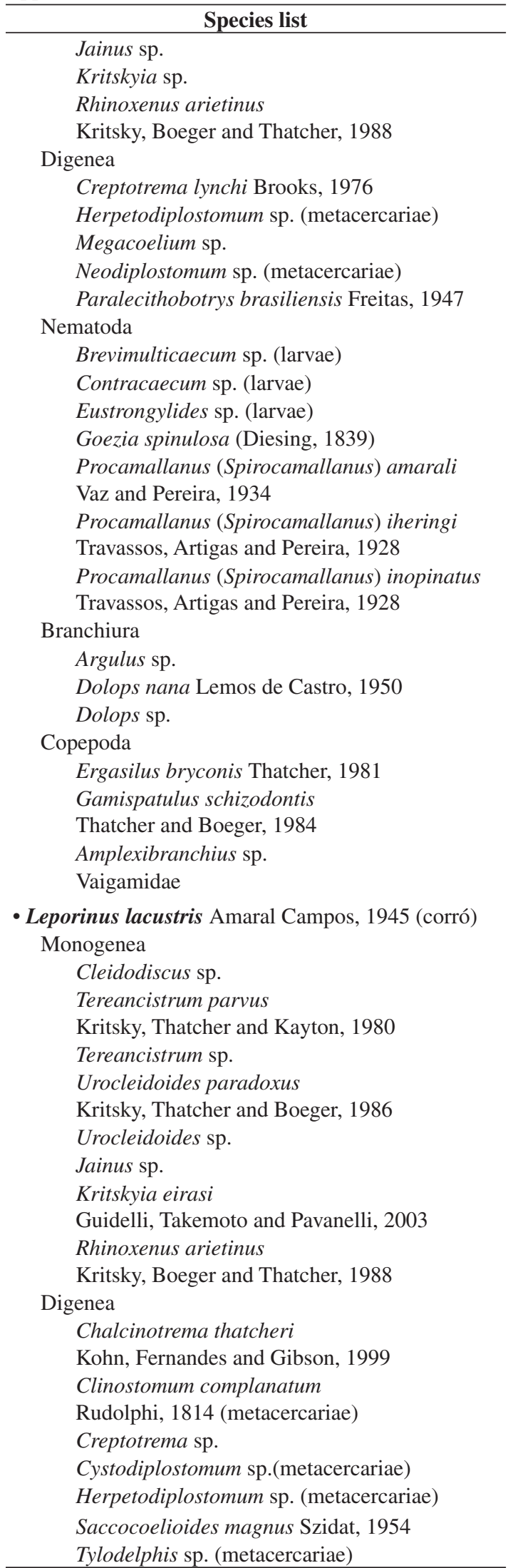

Appendix 1. Continued...

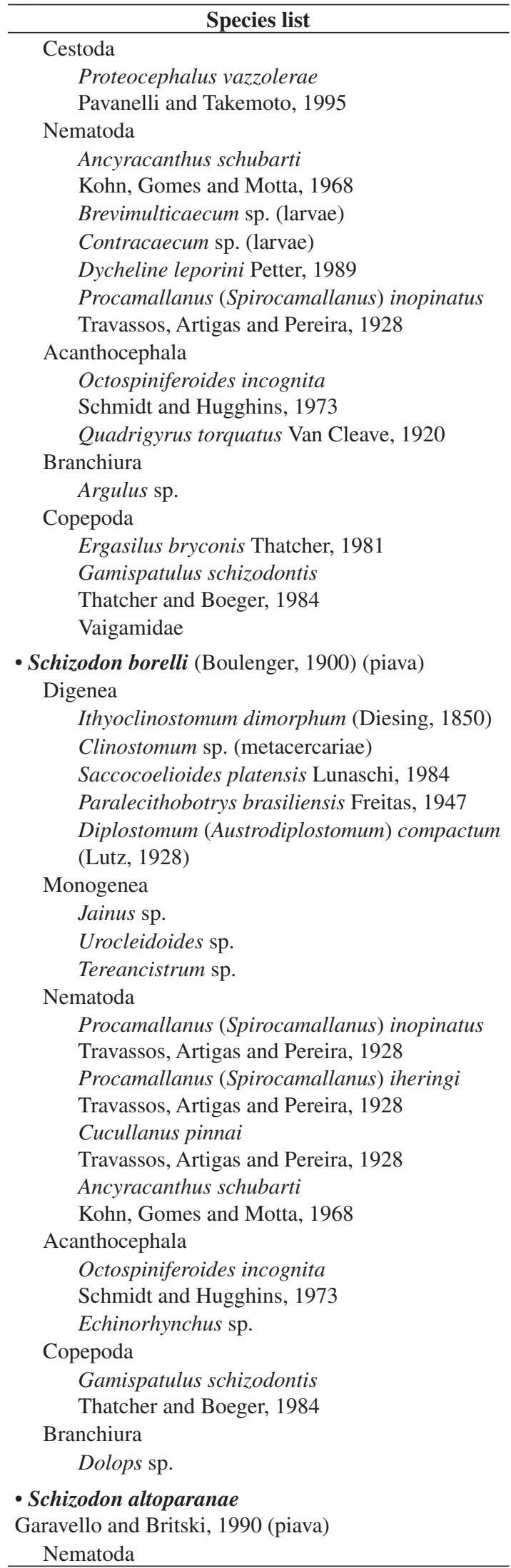


Appendix 1. Continued...

\begin{tabular}{l} 
Species list \\
\hline Procamallanus sp. \\
Acanthocephala \\
- Schizodon nasutus Kner, 1858 (piava) \\
Monogenea \\
Curimatidae \\
- Cyphocharax nagelii (Steindachner, 1881) (saguiru) \\
Digenea \\
Diplostomum sp. (metacercariae) \\
Tylodelphis sp. (metacercariae) \\
- Cyphocharax modestus \\
(Fernández-Yépez, 1948) (saguiru) \\
Digenea (metacercariae) \\
- Steindachnerina insculpta \\
(Fernández-Yépez, 1948) (saguiru) \\
Monogenea \\
Urocleidoides sp. \\
Digenea \\
Diplostomum sp. (metacercariae) \\
Nematoda \\
Travnema travnema Pereira,1938 \\
Cosmoxynema vianai Travassos, 1949
\end{tabular}

\section{Prochilodontidae}

- Prochilodus lineatus

(Valenciennes, 1837) (curimba)

Protozoa

Trypanosoma scrofae Eiras and Pavanelli, 1989

Myxosporea

Henneguya paranaensis

Eiras, Pavanelli and Takemoto, 2004

Monogenea

Rhinonastes pseudocapsaloideum

Kritsky, Thatcher and Boeger, 1988

Kritskyia boegeri

Takemoto, Lizama and Pavanelli, 2002

Tereancistrum curimba

Lizama, Takemoto and Pavanelli, 2004

Tereancistrum toksonum

Lizama, Takemoto and Pavanelli, 2004

Tereancistrum sp.

Gyrodactylus sp.1

Anacanthoroides sp.

Ancyrocephalinae

Digenea

Saccocoelioides magnorchis Thatcher, 1978

Saccocoelioides nanii Szidat, 1954

Unicoelium prochilodorum

Thatcher and Dossman, 1975

Megacoelium sp.

Saccocoelioides leporinodus Thatcher, 1978

Saccocoelioides saccodontis Thatcher, 1978

Saccocoelioides sp.

Tylodelphis sp. (metacercariae)

Colocladorchis sp.

Sphinterodiplostomum sp. (metacercariae)
Appendix 1. Continued..

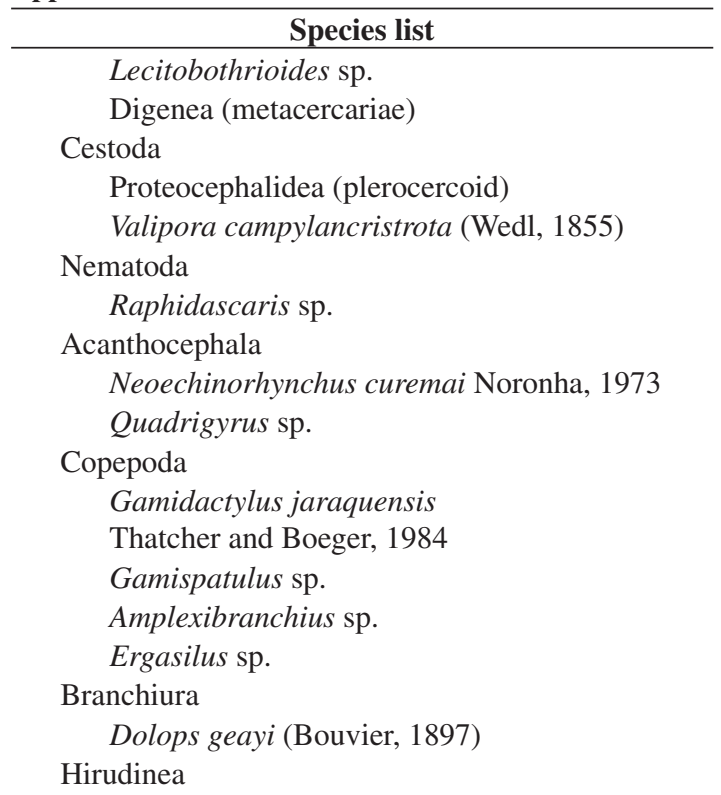

\section{Erythrinidae}

- Hoplias aff. malabaricus (Bloch, 1794) (traíra)

Digenea

Clinostomum complanatum

Rudolphi, 1814 (metacercariae)

Prosthenhystera sp.

Ithyoclinostomum dimorphum

(Diesing, 1850) (metacercariae)

Diplostomum sp. (metacercariae)

Diplostomum (Tylodelphys) sp.1

(metacercariae)

Diplostomum (Tylodelphys) sp.2

(metacercariae)

Pseudosellacotyla lutzi (Freitas, 1941)

Sphincterodiplostomum musculosum

Dubois, 1936 (metacercariae)

Diplostomum (Austrodiplostomum) compactum

(Lutz, 1928) (metacercariae)

Thometrema overstreeti

(Brooks, Mayes and Thorson, 1979)

Nematoda

Eustrongylides ignotus

Jäegerskiold, 1909 (larvae)

Contracaecum sp. (larvae)

Porrocaecum sp. (larvae)

Paracapillaria piscicola

(Travassos, Artigas and Pereira, 1928)

Procamallanus (Procamallanus) peraccuratus

Pinto, Fábio, Noronha and Rolas, 1976

Procamallanus (Spirocamallanus) inopinatus

Travassos, Artigas and Pereira, 1928

Goezia spinulosa (Diesing, 1839)

Acanthocephala

Quadrigyrus machadoi Fábio, 1983

Pentastomida

Sebekia oxycephala Sambon, 1922

Isopoda 
Appendix 1. Continued...

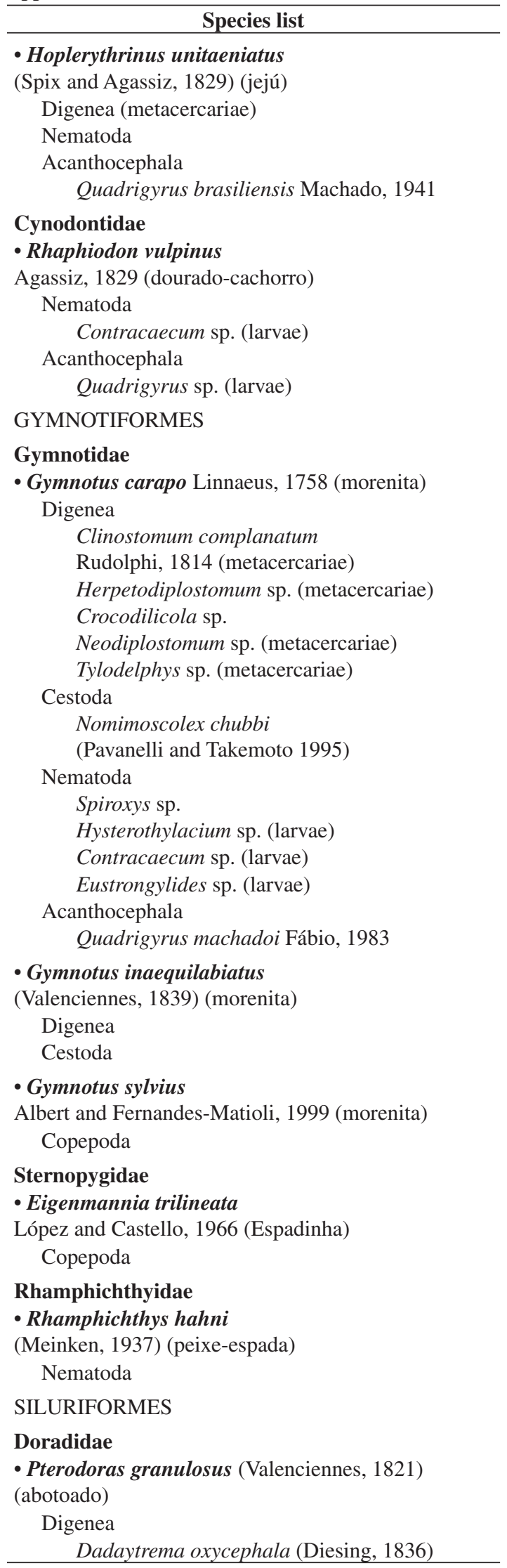

Appendix 1. Continued...

\begin{tabular}{l}
\hline \multicolumn{1}{c}{ Species list } \\
\hline Cestoda \\
Monticellia belavistensis \\
Pavanelli, Santos and Takemoto, 1994 \\
Nematoda \\
Rondonia rondoni Travassos, 1920 \\
Acanthocephala \\
- Rhinodoras dorbignyi (Kner, 1855) (armado) \\
Nematoda \\
- Trachydoras paraguayensis \\
(Eigenmann and Ward, 1907) (armadinho) \\
Monogenea \\
Vancleaveus sp. \\
Digenea \\
Strigeoidea (metacercariae) \\
Nematoda \\
Procamallanus sp. \\
Cosmoxynemoides sp.
\end{tabular}

\section{Auchenipteridae}

- Auchenipterus osteomystax

(Miranda Ribeiro, 1918) (surumanha)

Monogenea Demidospermus sp.

Digenea

Diplostomum (Austrodiplostomum) compactum
(Lutz, 1928) (metacercariae)
Creptotrema creptotrema
Travassos, Artigas and Pereira, 1928
Microrchis oligovitellum Lunaschi, 1987
Crocodilicola sp.
Clinostomum complanatum Rudolphi, 1814
(metacercariae)
Strigeidae (metacercariae)
matoda
Procamallanus (Spirocamallanus) sp.
Johnstonmawsonia sp.
Rhabdochona acuminata (Molin, 1860)
pepoda

- Parauchenipterus galeatus

(Linnaeus, 1766) (cangati)

Monogenea

Digenea

Microrchis oligovitelum Lunaschi, 1987

Clinostomum complanatum

Rudolphi, 1814 (metacercariae)

Cestoda

Cangatiella arandasi

Pavanelli and Machado dos Santos, 1991

Nematoda

Cucullanellus sp.

Goezia sp.

Ageneiosidae

-Ageneiosus brevifilis Valenciennes, 1840 (manduvê) Cestoda

Gibsoniela mandube (Woodland, 1935) 
Appendix 1. Continued...

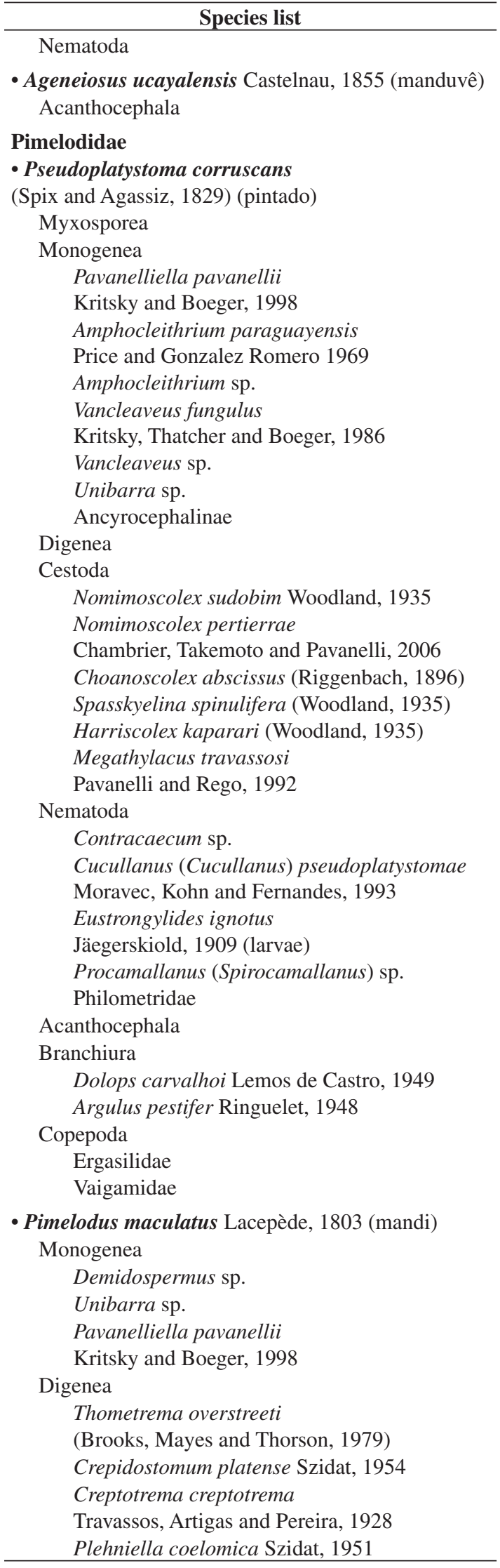

Appendix 1. Continued...

\begin{tabular}{|c|}
\hline $\begin{array}{c}\text { Species list } \\
\end{array}$ \\
\hline Prosthenhystera obesa (Diesing,1850) \\
\hline Clinostomum sp. (metacercariae) \\
\hline Diplostomum sp. (metacercariae) \\
\hline Cestoda \\
\hline Monticellia loyolai \\
\hline Pavanelli and Machado dos Santos, 1992 \\
\hline Nomimoscolex sp. \\
\hline Valipora sp. \\
\hline Nematoda \\
\hline Cucullanus pinnai \\
\hline Travassos, Artigas and Pereira, 1928 \\
\hline Spirocamallannus sp. \\
\hline Philometra sp. \\
\hline Monhysterides sp. \\
\hline Goezia sp. \\
\hline Contracaecum sp. (larvae) \\
\hline Eustrongylides sp. (larvae) \\
\hline Acanthocephala \\
\hline Neoechinorhynchus sp. \\
\hline Quadrigyrus machadoi Fábio, 1983 \\
\hline Copepoda \\
\hline Ergasilus sp. \\
\hline Vaigamus sp. \\
\hline Therodamas sp. \\
\hline Gamidactylus sp. \\
\hline Hirudinea \\
\hline Helobdela sp. \\
\hline Myzobdella sp. \\
\hline Isopoda \\
\hline Telotha sp. \\
\hline - Pimelodus ornatus Kner, 1858 (mandi) \\
\hline Cestoda \\
\hline Mariauxiella pimelodi \\
\hline Chambrier and Rego, 1995 \\
\hline Spasskyelina sp. \\
\hline • Hemisorubim platyrhynchos \\
\hline (Valenciennes, 1840) (jurupoca) \\
\hline Digenea \\
\hline Crocodilicola pseudostoma \\
\hline (Willemoes-Suhm, 1870) \\
\hline Sanguinicola platyrhynchi \\
\hline Guidelli, Isaac and Pavanelli, 2002 \\
\hline Sphincterodiplostomum sp. \\
\hline Gorgoderidae \\
\hline Cestoda \\
\hline Goezeella paranaensis \\
\hline Pavanelli and Rego, 1989 \\
\hline Spatulifer maringaensis \\
\hline Pavanelli and Rego, 1989 \\
\hline Chambriella itaipuensis \\
\hline (Pavanelli and Rego, 1991) \\
\hline Mariauxiella piscatorum \\
\hline Chambrier and Vaucher, 1999 \\
\hline Nematoda \\
\hline Contracaecum sp. (larvae) \\
\hline
\end{tabular}


Appendix 1. Continued...

\section{Species list}

Cucullanus (Cucullanus) zungaro

Vaz and Pereira, 1934

Eustrongylides ignotus

Jägerskiöld, 1909 (larvae)

Goezia sp.

Acanthocephala

Quadrigyrus machadoi Fábio, 1983

Pentastomida

- Iheringichthys labrosus (Lütken, 1874) (mandi)

Monogenea

Demidospermus labrosi

França, Isaac, Pavanelli and Takemoto, 2003

Demidospermus mandi

França, Isaac, Pavanelli and Takemoto, 2003

Pseudovancleaveus paranaensis

França, Isaac, Pavanelli and Takemoto, 2003

Digenea

Herpetodiplostomum sp. (metacercariae)

Cestoda

Proteocephalidea

Nematoda

Procamallanus (Spirocamallanus) pimelodus

Pinto, Fábio, Noronha and Rolas, 1974

Contracaecum sp.

Acanthocephala

Quadrigyrus sp.

- Rhamdia quelen (Quoy and Gaimard, 1824) (bagre)

Digenea (metacercariae)

- Pinirampus pirinampu

(Spix and Agassiz, 1829) (barbado)

Monogenea

Omothecium sp.

Unibarra sp.

Digenea (metacercariae)

Cestoda

Nomimoscolex admonticelia (Woodland, 1934)

Rudolphiella piranabu (Woodland, 1934)

Nematoda (larvae)

Copepoda

Vaigamidae

- Sorubim lima (Bloch and Schneider, 1801) (chinelo)

Cestoda

Spatulifer maringaensis

Pavanelli and Rego, 1989

Paramonticellia itaipuensis

Pavanelli and Rego, 1991

Nupelia portoriquensis

Pavanelli and Rego, 1991

Goezeella nupeliensis

Pavanelli and Rego, 1991

- Zungaro zungaro (Humboldt, 1821) (jaú)

Cestoda

Travassiella avitellina

Rego and Pavanelli, 1987
Appendix 1. Continued...

\begin{tabular}{l} 
Species list \\
\hline Peltidocotyle rugosa Diesing, 1850 \\
Megathylacus brooksi \\
Rego and Pavanelli, 1985 \\
Jauella glandicephalus \\
Rego and Pavanelli, 1985 \\
Chambriella agostinhoi \\
Pavanelli and Santos, 1992 \\
Choanoscolex abscissus (Riggenbach, 1895) \\
Nematoda \\
Cucullanus sp.
\end{tabular}

Hypophthalmidae

- Hypophthalmus edentatus

Spix and Agassiz, 1829 (mapará)

Nematoda

Callichthyidae

- Hoplosternum littorale (Hancock, 1828) (tamboatá)

Digenea

Clinostomum complanatum

Rudolphi, 1814 (metacercariae)

Loricariidae

- Loricariichthys platymetopon

Isbrücker and Nijssen, 1979 (cascudo-chinelo)

Monogenea

Digenea

Clinostomum complanatum

Rudolphi, 1814 (metacercariae)

Crocodilicola pseudostoma

(Willemoes-Suhm, 1870) (metacercariae)

Nematoda

Raphidascaris (Sprentascaris) mahnerti

(Petter and Cassone, 1984)

- Loricariichthys rostratus

Reis and Pereira, 2000 (cascudo-chinelo)

Digenea (metacercariae)

- Hypostomus regani (Ihering, 1905) (cascudo-chita)

Digenea

Diplostomum (Austrodiplostomum) compactum

(Lutz, 1928) (metacercariae)

\section{- Rhinelepis aspera}

Spix and Agassiz, 1829 (cascudo-preto)

Protozoa

Trypanosoma nupelianus

Eiras, Rego and Pavanelli, 1990

- Megalancistrus parananus

(Peters, 1881) (cascudo-abacaxi)

Protozoa

Trypanosoma guairaensis

Eiras, Rego and Pavanelli, 1989

Hirudinea

SYNBRANCHIFORMES

Synbranchidae

- Synbranchus marmoratus Bloch, 1795 (mussum) Digenea 
Appendix 1. Continued...

\begin{tabular}{l} 
Species list \\
\hline PERCIFORMES \\
Sciaenidae \\
- Plagioscion squamosissimus (Heckel, 1840) (curvina) \\
Monogenea \\
Diplectanum piscinarius \\
Kritsky and Thatcher, 1984 \\
Digenea \\
Diplostomum (Austrodiplostomum) compactum \\
(Lutz, 1928) (metacercariae) \\
Nematoda (larvae)
\end{tabular}

\section{Cichlidae}

- Geophagus proximus (Castelnau, 1855) (acará)

Monogenea

Sciadicleithrum sp.1

Sciadicleithrum sp.2

Digenea

Ascocotyle sp. (metacercariae)

Nematoda

Raphidascaris (Sprentascaris) sp.

Acarina

- Satanoperca pappaterra (Heckel, 1840) (acará)

Monogenea

Cleidodiscus sp.

Sciadicleithrum sp.

Digenea

Diplostomum (Austrodiplostomum) compactum (Lutz, 1928) (metacercariae)

Ascocotyle sp. (metacercariae)

Cestoda

Proteocephalidea (plerocercoid)

Nematoda

Copepoda

- Cichla kelberi Kullander and Ferreira, 2006 (tucunaré)

Monogenea

Gussevia arilla Kritsky,

Thatcher and Boeger, 1986

Gussevia longihaptor (Mizelle and Kritsky, 1969)

Gussevia undulata

Kritsky, Thatcher and Boeger, 1986

Digenea

Clinostomum sp. (metacercariae)
Appendix 1. Continued...

\section{Species list}

Diplostomum (Austrodiplostomum) compactum (Lutz, 1928) (metacercariae)

Diplostomum sp. (metacercariae)

Cestoda

Proteocephalus macrophalus (Diesing, 1850)

Proteocephalus microscopicus (Woodland, 1935)

Sciadocephalus megalodiscus Diesing, 1850

Nematoda

Contracaecum sp. (larvae)

Acanthocephala

Quadrigyrus machadoi Fábio, 1983 (larvae) Isopoda

- Astronotus crassipinnis (Heckel, 1840) (oscar)

Monogenea

Gussevia asota

Kritsky, Thatcher and Boeger, 1989

Gussevia astronoti

Kritsky, Thatcher and Boeger, 1989

Gussevia rogersi

Kritsky, Thatcher and Boeger, 1989

Gussevia sp.

- Crenicichla britskii Kullander, 1982 (joaninha)

Monogenea

Sciadicleithrum sp.

Digenea

Cestoda

Valipora sp.

Nematoda

- Crenicichla niederleinii (Holmberg, 1891) (joaninha)

Monogenea

Sciadicleithrum sp.

Digenea

Nematoda

- Cichlasoma paranaense Kullander, 1983 (cará)

Acanthocephala

- Laetacara sp. (cará)

Monogenea

Cleidodiscus sp.

Digenea 